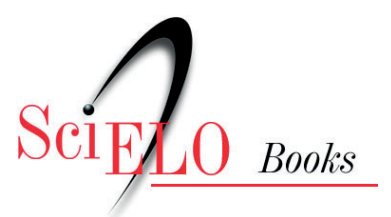

\title{
7. A EJA como educação popular desafios de uma experiência de alfabetização em interface com as novas tecnologias
}

\author{
Maria Clarisse Vieira
}

\section{SciELO Books / SciELO Livros / SciELO Libros}

VIEIRA, M.C. A EJA como educação popular: desafios de uma experiência de alfabetização em interface com as novas tecnologias. In: PAIVA, J., comp. Aprendizados ao longo da vida: sujeitos, políticas e processos educativos [online]. Rio de Janeiro: EDUERJ, 2019, pp. 151-171. Pesquisa em educação/Educação ao longo da vida series. ISBN: 978-65-990364-9-1.

https://doi.org/10.7476/9786599036491.0008.

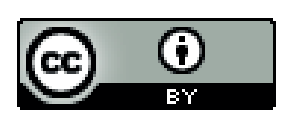

All the contents of this work, except where otherwise noted, is licensed under a Creative Commons Attribution 4.0 International license.

Todo o conteúdo deste trabalho, exceto quando houver ressalva, é publicado sob a licença Creative Commons Atribição $\underline{4.0}$.

Todo el contenido de esta obra, excepto donde se indique lo contrario, está bajo licencia de la licencia Creative Commons Reconocimento 4.0. 


\title{
7
}

\section{A EJA como educação popular: desafios de uma experiência de alfabetização em interface com as novas tecnologias}

\author{
Maria Clarisse Vieira
}

O lançamento do Marco de Referência da Educação Popular para Politicas Públicas (Brasil, 2014) reacendeu o debate acerca dos desafios e possibilidades da presença da educaçáo popular nos espaços formais e nas políticas públicas. A despeito de posicionamentos divergentes sobre essa aproximação, este não é um debate novo. O próprio Paulo Freire, em 1964, manifestou-se favorável à ideia de uma educaçâo pública popular, ao coordenar o Programa Nacional de Alfabetização e, posteriormente, de 1989 a 1991, quando foi Secretário Municipal de Educação em São Paulo, criou o Movimento de Alfabetização de Jovens e Adultos (MOVA-SP) (Gadotti, 2016).

Não obstante a educação popular ter vivido o seu apogeu na década de 1960, sua influência ainda se faz presente no Brasil e no mundo, no ideário e na prática de diversas organizaçóes populares. Para Brandão (2008), a educação popular não é uma escola pedagógica, nem uma proposta datada e situada em um tempo específico. Ela é uma vocação da educação, um instrumento político e cultural de força pedagógica a serviço das classes populares. 
Segundo ele, essa proposta educativa pode ser viabilizada a partir de duas posturas distintas e não antagônicas. Por um lado, com ênfase no seu viés político para preparar as classes populares para algum tipo de transformação social, subordinada a uma tomada de poder e à instauração de uma alternativa socialista à sociedade capitalista e opressora; e de outro, com ênfase no seu viés cultural, como forma de elevar, de uma maneira justa e não supletiva, a qualidade de vida dos excluídos, a começar pela oferta de um tipo de educação que instaure a plenitude da pessoa cidadã.

Brandáo (2008) também argumenta que, ao mesmo tempo em que é necessária a ampliação de experiências autônomas de uma educação realizada a partir da iniciativa dos movimentos populares, é também fundamental a redefinição da escola pública, de modo que ela venha a se transformar em uma educaçáo oferecida pelo Estado, mas que incorpora os anseios, interesses e necessidades das classes populares.

É impossível discutir a educação popular no contexto da educação de jovens e adultos sem fazer referência a Paulo Freire, um dos principais fundadores dessa concepção educativa. Segundo esse autor:

No Brasil e em outras áreas da América Latina, a Educação de Adultos viveu um processo de amadurecimento que vem transformando a compreensão que dela tínhamos poucos anos atrás. A Educação de Adultos é melhor percebida quando situamos hoje como Educação Popular [...] O conceito de Educação de Adultos vai se movendo na direção da Educação Popular na medida em que a realidade começa a fazer algumas exigências à sensibilidade e à competência científica dos educadores e das educadoras. Uma destas exigências tem a ver com a compreensão crítica dos educadores do que vem ocorrendo na cotidianidade do meio popular. Não é possível que educadoras e educadores pensem apenas os procedimentos didáticos e os conteúdos a serem ensinados aos grupos populares. Os próprios conteúdos a serem ensinados não 
podem ser totalmente estranhos àquela cotidianidade. O que acontece, no meio popular, nas periferias das cidades, nos campos, trabalhadores urbanos e rurais reunindo-se para rezar ou para discutir seus direitos. Nada pode escapar à curiosidade arguta dos educadores envolvidos na prática da educação popular (Freire, 2000, pp. 15-6).

A posição de Freire sobre educação popular deixa claro que esta náo pode se restringir ao cumprimento de programas, planos de cursos, planos de disciplinas, elaborados à revelia dos educandos, numa concepçáo bancária e autoritária da educaçáo. Segundo ele, os educadores e grupos populares compreendem que educaçáo popular é, sobretudo, o processo permanente de reflexão sobre a militância, ou seja, de refletir a sua capacidade de se mobilizar em direção a objetivos próprios. Nessa visão, o ato educativo compreendido como ato político náo se deixa aprisionar na estreiteza burocrática de procedimentos escolarizantes.

A perspectiva da educação popular encontra-se na gênese do Grupo de Ensino, Pesquisa e Extensão em Educação Popular e Estudos Histórico-culturais (GENPEX). Esse grupo, criado em 2000, tem suas origens relacionadas ao movimento de ocupação da região administrativa do Paranoá, em Brasília, iniciado com a construção da capital federal, quando brasileiros oriundos de diversas regióes do país migraram para a regiáo e iniciaram um processo de luta pela moradia e fixação no território. A luta em prol da posse definitiva da terra estrutura-se e torna-se sistematizada a partir dos anos 1970 e 1980, por meio da mobilização de um grupo de jovens ligados à igreja católica que iniciam um trabalho político pastoral de conscientização da comunidade. Esse grupo se organiza em uma associação de moradores e passa a pressionar, de forma mais efetiva, o poder público pela fixação da população e o fornecimento de serviços básicos como educação, saúde, água, luz, esgoto, segurança e transporte. 
É nesse contexto que percebem a educação de adultos como forma de fortalecer a luta e fixação da população na cidade, visto que a maioria dos moradores não era alfabetizada. Inicialmente, procurou-se apoio da igreja católica local. Para que o trabalho se expandisse, porém, necessitavam de apoio pedagógico. Como naquele momento esse apoio era negado pelo Estado, foram buscá-lo, em 1986, na Faculdade de Educação da Universidade de Brasília. Desde então a UnB desenvolve, em parceria com o Movimento Popular - Centro de Desenvolvimento e Cultura do Paranoá (CEDEP), trabalho educativo voltado à educação e formação de educadores(as) de jovens e adultos na região administrativa do Paranoá/Itapoá.

O objetivo deste artigo é propor um diálogo com a educação popular e a EJA, analisando nossos fazeres, especificamente a práxis desenvolvida desde 2015, em escola pública do Paranoá, em interface com as tecnologias. Para tanto, o artigo buscou apresentar a pertinência da alfabetização de jovens e adultos auxiliada pelo uso do computador no processo alfabetizador e a sua cooperação na inclusão digital, por meio da abordagem da situação-problema-desafio e do uso de texto coletivo na educação de jovens e adultos.

Do ponto de vista metodológico, o grupo opta pela pesquisa-ação, por reconhecer a necessidade de superar investigaçóes que se limitam a uma perspectiva diagnóstica e descritiva. De acordo com Michel Thiollent (1985, p. 14), a pesquisa-ação é um tipo de pesquisa social com base empírica, concebida e realizada em estreita associação com uma ação "[...] ou com uma resolução de um problema coletivo, e no qual os pesquisadores e os participantes representativos da situação ou problema estão envolvidos de modo cooperativo ou participativo". A pesquisa-ação não é constituída apenas pelo caráter participativo, mas inclui uma dimensão de produção de conhecimento, que pode ser útil náo 
apenas para a coletividade considerada na investigação, mas para um público mais amplo.

O processo de ação-reflexão-ação, realizado no interior da escola, possibilita a implicação do pesquisador, momento no qual este se engaja pessoal e coletivamente em uma práxis científica "[...] em função de sua história familiar e libidinal, de suas posiçóes passada e atual nas relaçóes de produção e de classe, de seu projeto sociopolítico em ato" (Barbier, 2002, p. 101). Este engajamento vem se traduzindo na parceria que há mais de trinta anos se construiu junto ao movimento popular do Paranoá-Itapoã, realizada semanalmente nas salas de alfabetização e no planejamento que a universidade realiza.

\section{O diálogo como referência das práticas}

Paulo Freire (2005, p. 77), quando discute a essência do diálogo, identifica na palavra o processo pelo qual se constitui o diálogo verdadeiro. A palavra, para que se faça transformadora da realidade, necessita ser resultante da ação e da reflexão. "Não há palavra verdadeira que não seja práxis. Daí dizer que a palavra verdadeira seja transformar o mundo". O diálogo, uma das categorias mais importantes em Freire, representa para a educação popular o alicerce para uma pedagogia libertadora e transformadora. Nesse sentido, a atuação em escola pública do Paranoá é parte e continuidade do trabalho educativo que o Genpex/FE/ UnB desenvolve desde 1986 com o Movimento Popular do Paranoá, inicialmente, com a Associação de Moradores do Paranoá e, de 1987 até os dias atuais, com o Centro de Cultura e Desenvolvimento do Paranoá (CEDEP).

O objetivo da cooperação Genpex/FE/UnB e Cedep é contribuir pedagogicamente com o processo de alfabetização e formação de alfabetizadores de jovens e adultos do Paranoá e Itapoã 
e, também, com o processo de formação dos(as) pedagogos(as) e demais licenciados da Universidade de Brasília.

Até 2015, essa práxis estava restrita aos espaços do Movimento Popular. No entanto, a partir desse período, esse desafio se estende à rede pública de ensino. Este processo de ampliação tem origem em 2011, com o lançamento do Programa DF Alfabetizado, que tem como base a Resolução CD/FNDE n. 32 (Brasil, 2011), fruto da adesão, ainda que tardia, do Governo do Distrito Federal ao Programa Brasil Alfabetizado (PBA), lançado em 2003. A referida parceria materializa-se na atuação conjunta do Cedep, Genpex e Coordenação Regional de Ensino visando à formação dos alfabetizadores do Paranoá e Itapoã e a criação de turmas na região. Foram viabilizadas quatro ediçóes do DF Alfabetizado, realizadas em 2012, 2013, 2014 e 2016. Estima-se que até 2014 houve o atendimento de quase mil educandos, em 52 turmas, com média de quinze alunos. Em 2015, por problemas operacionais relativos ao repasse de recursos para pagamento da bolsa aos alfabetizadores e transição governamental, não foi possível a realização do programa. Neste momento, o Movimento Popular questiona-se acerca da continuidade dos estudantes egressos do Programa DF Alfabetizado, na rede pública, na EJA. Onde estariam os estudantes egressos? Como estimular e contribuir no acesso e permanência desses estudantes no contexto da EJA?

Buscando responder a esse desafio, em 2015 iniciou-se uma articulação com integrantes da coordenação intermediária de EJA da Regional de Ensino para encontrar um espaço possível para o acompanhamento na rede pública. Esse trabalho tem ocorrido no laboratório de informática da escola, com todas as turmas de primeiro segmento da educação de jovens e adultos. $\mathrm{O}$ trabalho pedagógico tem como desafio integrar a informática, as linguagens de português e matemática e as situaçóes-problema-desafios vividas pelos estudantes da EJA, moradores/as do Paranoá e Itapoã. 
Para isso, os estudantes-pesquisadores da universidade avaliam e reencaminham, semanalmente, as ações pedagógicas realizadas.

\section{A perspectiva histórico-cultural e os eixos do trabalho na educação popular}

O referencial teórico tem como fundamento a perspectiva histórico-cultural que considera a constituição do sujeito parte intrínseca do desenvolvimento humano. Essa perspectiva incorpora a compreensão não apenas dos processos psicologizados da aprendizagem da criança, mas também contempla o sujeito adulto aprendiz em suas diferenças e singularidades, pois segundo Vygotsky (2006, p. 116), a diferença entre aprendizagem da criança e do sujeito adulto "[...] consiste nas diversas relaçóes das aprendizagens com o processo de desenvolvimento", o qual abarca vivências e experiências das quais o sujeito participa cotidianamente nos contextos sociais em que atua. Em outras palavras, as relaçóes entre aprendizagem e desenvolvimento do adulto consistem em que o sujeito vivencie o processo de "[...] converter-se em participante pleno de uma prática sociocultural, que compromete os propósitos de aprender de uma pessoa e configura o significado da aprendizagem" (Lave e Wenger, 1991, p. 1), ou seja, o sujeito aprende e desenvolve-se a partir das suas relaçóes e práticas sociais.

As relaçóes sociais do indivíduo e seu contexto cultural, que viabilizam a tessitura dessas redes, entretanto, não ocorrem de forma direta, mas sim a partir de processos de mediaçáo simbólica, efetuados por meio de instrumentos e signos constituídos historicamente. Essa forma de pensar o homem no aspecto histórico-cultural, desenvolvida por Vygotsky (2006), é considerada relevante pelo fato de lidar com sujeitos humanos e, como tal, a importância das relaçóes sociais, da história de vida, da fala, da escuta e da cultura em que estão inseridos. 
O trabalho pedagógico é composto pelos seguintes eixos: o acolhimento (amorosidade), a discussão de situaçóes-problema-desafios e os usos de textos coletivos. Um dos diferenciais do processo de alfabetização desenvolvido é o acolhimento, a "amorosidade" com que os(as) alfabetizandos(as) são tratados (Freire, 1996). Parte-se do pressuposto de que, quando se atua com pessoas às quais foi negado o acesso à escola e à própria língua escrita, trabalha-se com pessoas excluídas de várias formas, e que não têm como habitual tal acolhimento. Ser acolhido no processo de alfabetização garante o bem-estar do(a) educando(a) e, consequentemente, sua permanência no ambiente escolar.

A situação-problema-desafio se refere "[...] às necessidades amorosas/afetivas, econômicas, financeiras, sociais e culturais. Essas necessidades caracterizam o cotidiano vivido/enfrentado pelos moradores do Paranoá” (Vieira et al., 2015, p. 18). Em meio ao espaço de diálogo entre universidade e comunidade surgem essas situaçôes-problema-desafio, constituídas por propostas político-pedagógicas que vão ao encontro das necessidades levantadas pela comunidade. Elas são "[...] escolhidas com discussão, defesa de posição, votação com maioria simples ou absoluta. Tornam-se o eixo dorsal de referência do processo alfabetizador" (Vieira et al., 2015, p. 20). A partir das discussóes surgem os encaminhamentos individuais e coletivos com o propósito de superar essas questóes.

O texto coletivo é um processo de transcrição da palavra oral em texto escrito. De acordo com Menezes (2013, p. 12), “[...] a construção do texto coletivo inicia-se no momento em que alfabetizandos e alfabetizadores, num diálogo tecido com base na escolha da situação-problema-desafio se expressam e discutem as dificuldades vivenciadas no dia-a-dia”. A partir dos registros oriundos da oralidade são produzidos textos que se transformam em atividades, as quais envolvem a língua portuguesa, matemática, história, geografia e outros conteúdos. $\mathrm{O}$ intuito é valorizar a 
voz dos(as) educandos(as), trabalhar a partir de questóes propostas por eles(as) mesmos(as) e que dizem respeito à sua realidade, e encaminhar soluçóes aos problemas vividos na comunidade.

\section{O diálogo entre EJA, tecnologias e educação popular na escola pública}

O trabalho de pesquisa-ação ocorre no laboratório de informática, no período noturno, de segunda a quinta-feira, no horário das $19 \mathrm{~h} 20 \mathrm{~min}$ às $21 \mathrm{~h} 20 \mathrm{~min}$, e envolve as quatro etapas do primeiro segmento da EJA. A cada semestre o número de alunos(as) que participa das atividades varia. No ano de 2015, participaram cerca de cem educandos(as). Destes, 49\% tinham faixa etária superior a 51 anos; 3\% abaixo de 30 anos; 20\% entre 31 e 40 anos; 10\% entre 40 e 50 anos; e 18\% não declararam a idade (Reis e Sobral, 2017). A maioria dos educandos da EJA que participa das atividades afirma que nunca teve contato com o computador, a não ser para limpar a máquina ou comprar o computador para os filhos/netos. Nesse aspecto, além do trabalho educativo de alfabetização e integração das linguagens de matemática e português, o grupo realiza a inclusão digital. Segundo Coelho e Cruz (2008, p. 14), deixar de oferecer aos sujeitos da EJA “[...] a possibilidade de adquirir os conhecimentos necessários a este novo código de comunicação da sociedade tecnológica é negar-lhes o direito à plena cidadania, dada a penetraçáo generalizada das tecnologias digitais na vida contemporânea". Ou seja, sem o acesso a esse conhecimento, "[...] terão limitadas oportunidades de acessar informações em sites de órgãos governamentais, sindicais, de ONGs, informaçóes das quais dependem muitos de seus interesses como pessoas, como trabalhadores, como cidadãos" (Coelho e Cruz, 2008, p. 14). 
As atividades desenvolvidas têm como objetivo a inclusão digital e a articulação dos conteúdos trabalhados em sala de aula com português e matemática, contribuindo com a vida cotidiana dos estudantes, de forma que o computador possa servir como instrumento que facilite suas rotinas. Os problemas enfrentados por esses sujeitos, sejam de forma coletiva ou individual, sáo levantados e discutidos, com o intuito de buscar soluçóes para esses problemas.

Sr. Valter toma a palavra e começa a se recordar da falta da Internet na escola. Diz, em outras palavras, que isso é uma irresponsabilidade com o dinheiro público. Afirma que o pessoal da regional deveria estar na escola todos os dias. [...] A turma decide, para o nosso próximo encontro, trabalhar o abaixo-assinado sobre a Internet que já começou a ser trabalhado no semestre passado (Diário de bordo coletivo, 2016).

A proposta é feita coletivamente entre os(as) estudantes e professores(as) com vista a desenvolver um trabalho pedagógico que considere as histórias de vida e o cotidiano dos(as) estudantes e, para a execução desse trabalho, o computador aparece como uma ferramenta. Portanto, o Grupo da FE/UnB náo apresenta um planejamento pronto, mas o desenvolve em conjunto com os(as) educandos(as) da EJA, dando a eles(as) voz ativa. Segundo Freire (1996), a alfabetização precisa ser entendida em uma abordagem criadora, em que os(as) alfabetizandos(as) são sujeitos capazes de conhecer e não apenas como incidências do trabalho docente dos(as) alfabetizadores(as).

Um dos(as) educandos(as), o Sr. Pedro, durante uma das atividades no laboratório de informática, no segundo semestre de 2016, afirmou que "[...] apertar o botão e náo pensar, náo adianta”. Por isso, a proposta de intervençáo desenvolvida no grupo de pesquisa não se baseia em apenas capacitar os(as) estudantes da EJA a operar um computador, mas a ler o mundo e, a partir de 
reflexão e inserção crítica, transformá-lo. Todo o processo valoriza e respeita a voz e a história do sujeito, com forte vínculo com os princípios da educação popular.

Segundo Brandão (2008), a educação popular compreende os seus sujeitos como atores ativos de um tipo de trabalho ao redor do ensinar-e-aprender. Ela concebe seus sujeitos como pessoas humanas e como atores sociais, cujos direitos à participação nos processos de decisáo sobre suas vidas e da sociedade em que vivem ultrapassam o âmbito da escola. Assume, portanto, o desafio da formação integral, crítica e criativa dos educandos, de modo que o ensinar a ler as palavras seja precedido da leitura do mundo. Parte, portanto, de uma concepção humanizadora de pedagogia, tal como preconiza Freire (2014, p. 77), no qual ao invés de me "[...] sobrepor aos oprimidos e continuar mantendo-os como quase 'coisas', com eles estabeleço uma relaçáo dialógica permanente". Percebe-se o vínculo do trabalho com a educaçáo popular.

A seguir, são descritos algumas atividades e projetos desenvolvidos a partir de 2015, cuja referência são as histórias de vida, a situação-problema-desafio e o texto coletivo.

\section{A articulação da linguagem tecnológica com a alfabetização}

Para romper a marca do silêncio que caracteriza os(as) educandos(as) da EJA, o trabalho pedagógico em cada semestre se inicia com uma roda de autoapresentação, na qual se estimula a participação, o diálogo e a voz do(a) educando(a). A partir de um diagnóstico inicial, são propostas atividades que articulam conhecimentos prévios de informática ao processo de alfabetização e escolarização. Em 2015, foram desenvolvidos dois grandes projetos resultantes das discussóes e atividades elaboradas no laboratório de informática. 
O primeiro foi a construção de um livro com receitas regionais. A despeito da atividade com receitas ser comum na EJA, o trabalho foi articulado às histórias de vida, valorizando a identidade cultural do(a) educando(a). O trabalho foi realizado coletivamente no laboratório. Os(as) estudantes digitaram textos, fizeram leituras e trabalharam com imagens e fotografias. Além da produção coletiva, buscou-se discutir as origens históricas de cada receita, estimulando o seu processo de escolha democrática. $\mathrm{O}$ entusiasmo dos sujeitos nessa atividade foi acompanhado da verbalização de suas histórias de vida, o que levou o grupo a propor a elaboração do livro com histórias de vida.

Esta proposta foi formada a partir de histórias de vida de cada estudante. Juntamente com as histórias, foram trabalhadas imagens do livro do fotógrafo Evandro Teixeira, elaborado em comemoração aos 70 anos da obra Vidas Secas de Graciliano Ramos. Essas imagens retratavam a realidade que muitos sujeitos haviam vivenciado na infância e juventude. Os(as) estudantes tiveram acesso digital e impresso às imagens do livro de fotografia. Depois que viram todas elas, selecionaram algumas que chamaram atenção ou que estivessem relacionadas a suas próprias histórias de vida. Quando escolheram as imagens deram um título para cada uma delas e escreveram pequenos textos relacionando as imagens escolhidas com situaçóes vividas na infância. 
Figura 1: Queria ter um jumento desses

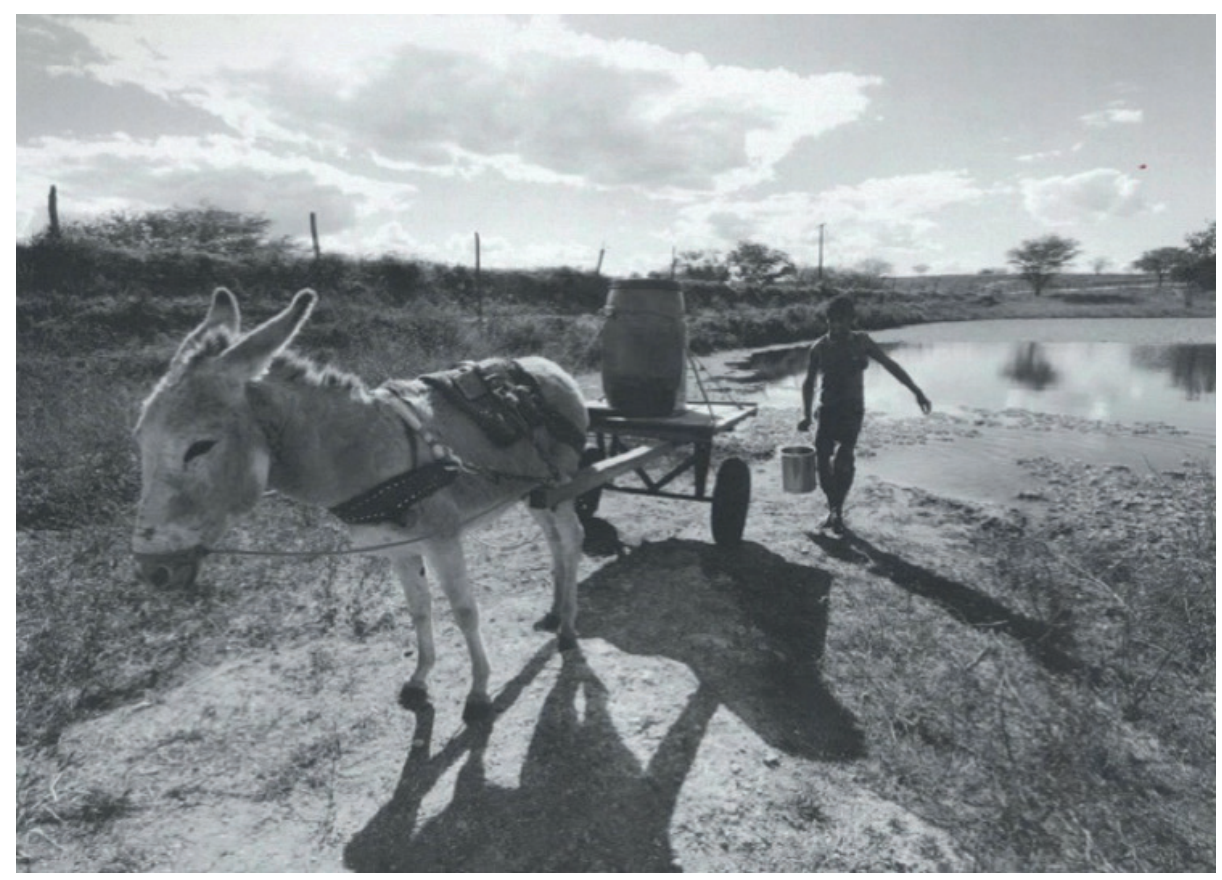

Fonte: Comentário de uma estudante para justificar a legenda na imagem do livro de Evandro Teixeira para sua história de vida, inscrita no Livro de Histórias de Vida, 2015: "[...] quando eu era criança eu via muito esse jumento. Queria que minha mãe tivesse um jumento desse para levar as coisas dela”.

De acordo com Reis e Sobral (2017), a elaboração do livro de história de vida engloba a escuta elaborativa individual e coletiva de histórias de vida, quando os pesquisadores registram de forma manuscrita o relato de cada estudante. Para a escrita do texto individual, utilizou-se roteiro com questóes norteadoras, sobre o qual o estudante respondia à mão e, depois, inseria as respostas no computador. Segundo eles, apenas dois ou três estudantes solicitaram que suas histórias não fossem registradas no livro, uma vez que "há muita tristeza no passado" e, sem dúvida, foram atendidos, considerando o respeito aos(às) educandos(as) e à formação ética, posta em meio ao processo educativo. Os demais socializaram suas histórias no livro, que chegou a ser exposto em amostra na semana da EJA, ocorrida em setembro de 2015. 
A seguir, apresentamos uma das histórias de vida, de D. Ana Maria Santos:

Moro no Itapoã e vim para Brasília em 1976. Antes vivi toda a minha vida em casa de família, desde os 8 anos e era castigada por causa dos filhos do patrão que faziam as coisas erradas, eu falava e o patrão não acreditava e, para corrigir, a gente era castigada. Cada dia que passa a vida vai melhorando, olho para trás e vejo como a vida está abençoada.

Segundo Arroyo (2005, p. 24), os sujeitos da EJA “[...] carregam trajetórias perversas de exclusão social, vivenciam trajetórias de negaçấo dos direitos mais básicos à vida, ao afeto, à alimentação, à moradia, ao trabalho e à sobrevivência". Pertencentes à classe trabalhadora, esses sujeitos, ao mesmo tempo em que vivenciam processos de exclusão social - materializados em segregação cultural, espacial, étnica e econômica -, experimentam, cotidianamente, o abalo de seu sentimento de pertença social e o bloqueio de perspectivas de futuro na sociedade. Seus percursos colocam em xeque a linearidade do pensar e do fazer pedagógicos, interrogando as bases que estruturam a docência e a pedagogia. As propostas de educaçáo de jovens e adultos sob a influência do ideário da educaçáo popular, ao enfocarem esse conflito, assumem atitude no sentido de superar o quadro de desigualdade social que se faz presente nos processos escolares e não escolares.

\section{A escrita do nome como processo de constituiçáo da identidade}

Barros (2016) desenvolveu uma pesquisa que revela como as significações que permeiam a escrita do próprio nome podem auxiliar na construção da identidade de sujeitos da educação de jovens e adultos. De acordo com o autor, a escrita do nome é 
determinante no processo de apropriação da identidade dos sujeitos, pois resulta no fortalecimento de sua dignidade e exercício da cidadania. Segundo ele, o processo de significação do nome resgata a autoestima dos(as) estudantes da EJA, amplia a visão que eles(as) têm acerca de suas vidas e favorece também a compreensão das suas histórias de vida, pois ao escreverem seus próprios nomes, sentem-se lembrados(as) e reconhecidos(as). Galvão e Di Pierro (2007, pp. 23-4) salientam que:

No contexto urbano letrado, a impressão da digital se torna a marca evidente do estigma de inferioridade atribuído ao analfabeto e as situaçóes de identificação pública passam a ser vividas como humilhação. Por esse motivo, a assinatura - o desenho do nome - é a primeira aprendizagem aspirada por qualquer adulto em processo de alfabetização.

Com base nesse estudo, no primeiro semestre de 2017, as atividades buscaram valorizar a escrita do nome a partir da compreensão de que o processo de alfabetização do(a) educando(a) representa um passo importante em sua entrada no mundo da escrita. A escrita do nome próprio proporciona a percepçáo de si como um ser social, englobando sua identidade, sua filiaçáo e sua história.

Segundo Justo (2017), em um dos dias em que a atividade foi realizada, metade da turma estava presente. Foi discutido o que achavam de seus nomes, se conheciam seu significado e se sabiam alguma história oral sobre seus nomes que gostariam de contar. A autora relata o depoimento de uma educanda:

A gente morava na roça e nenhum era registrado. Aí colocaram meu nome de Luciana, mas eu não gostava. Aí eu troquei por M. L. porque eu achava bonito. Mudei também o sobrenome porque dos meus irmãos era Amorim e eu achava que, como a gente tinha um sobrenome que era igual ao de um tecido branco, bem branquinho, então pensei: como vou 
colocar um sobrenome de um tecido branco se eu sou preta? Aí eu troquei para M. L. R. da C. (Trecho de diário de bordo de uma estudante).

O depoimento dessa aluna mostra como ela rompeu barreiras, pois, naquela época, na condição de mulher e negra, não era algo fácil assumir sua identidade racial, porque fatores de várias ordens dificultavam esse reconhecimento. Assim, ela transpassou paradigmas culturais, sociais e discriminatórios que perduravam naqueles tempos e que a impediam de estar satisfeita com seu nome.

A atividade proporcionou aos(às) estudantes conhecer o significado do próprio nome, reconhecer a escrita do nome usando a fonte do computador e diferenciando as letras que o compóem. A assimilação da importância do nome e sua função social trouxe momentos de reflexão sobre o significado em relação aos seus conceitos, ou seja, se seus nomes estavam relacionados com suas personalidades e valores. $\mathrm{O}$ acesso à internet permitiu identificar informaçóes sobre os significados. Após este processo de reflexáo e pesquisa, os(as) estudantes leram e digitaram as histórias e os significados dos nomes que foram encontrados no computador.

Concomitante a isso, outra parte dos(as) educandos(as) desenvolveu uma atividade de colagem, por meio de alfabeto móvel, cujas letras eram utilizadas para construírem no papel seu nome e sobrenome, o nome da regiáo ou o nome da sua cidade de origem. À medida que terminavam, os(as) educandos(as) iam até o quadro, onde estava o mapa do Brasil, e lá, junto com os participantes do Genpex que orientavam a atividade, encontravam a cidade, o estado e a regiáo de onde vieram. Uma das alunas encheu os olhos de água quando encontrou sua cidade, pois disse que ficava muito emocionada quando se lembrava de onde tinha vindo (Justo, 2007). 


\section{Histórias do Paranoá de ontem e de hoje como situaçáo-problema-desafio e texto coletivo}

Além do trabalho com os nomes, desenvolveu-se atividade sobre a história do lugar onde viviam. O que foi proposto foi a ressignificação do olhar do(a) educando(a), por meio da problematização, a fim de que percebessem o seu entorno como algo construído historicamente e que, portanto, como agentes históricos, suas escolhas constituíam a construção histórica. No dia dessa atividade, todos(as) os(as) alunos(as) da turma se reuniram no laboratório de informática para assistir a um vídeo produzido por alunos do ensino médio do Centro Educacional Darcy Ribeiro - escola pública localizada na cidade do Paranoá, que retrata a história do Paranoá desde o início da cidade até os dias de hoje.

Figura 2: Turma de EJA em atividade

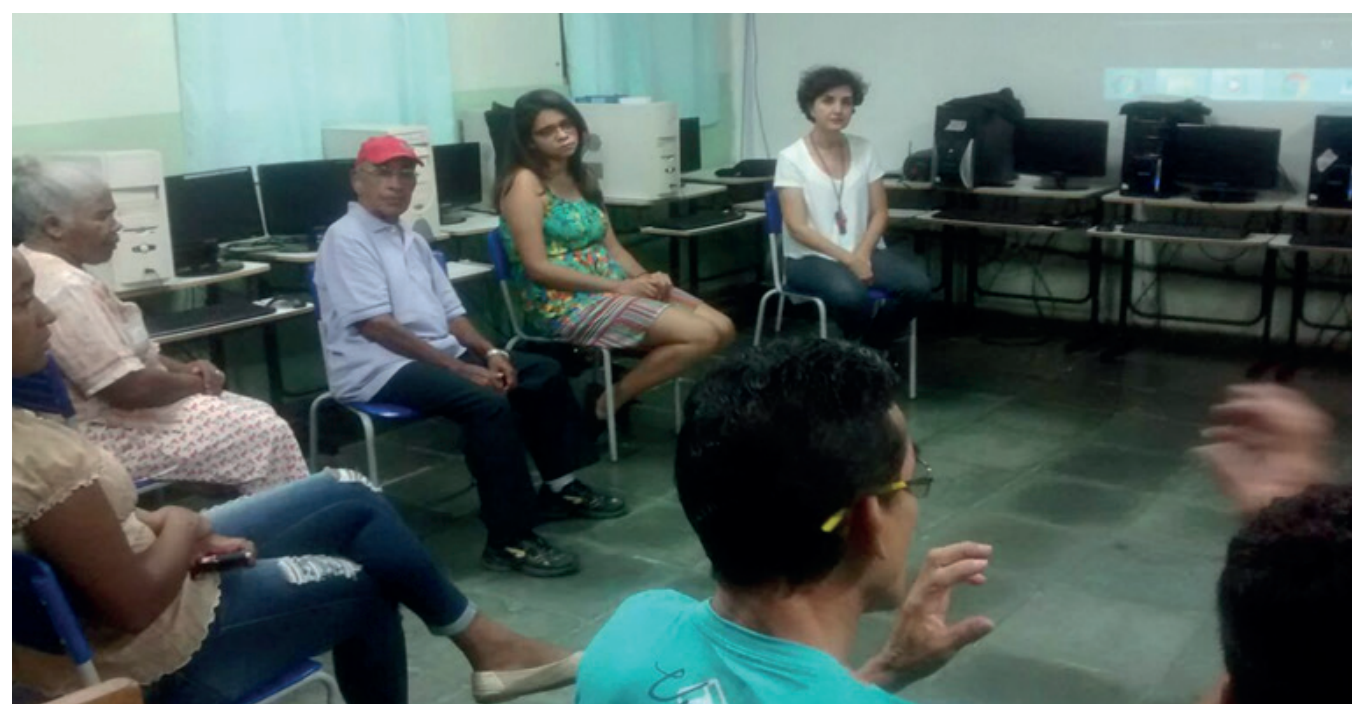

Fonte: Acervo do Genpex/FEA/UnB

O vídeo tratava das experiências enfrentadas pelos pioneiros da cidade, suas conquistas e dificuldades, e os avanços e qualidades do local. Durante a exposição do vídeo, percebemos que alguns alunos se lembravam de algumas coisas da época e sussurravam uns com os outros sobre os momentos que viveram. 
Após o vídeo, a continuação da atividade consistia em conhecer a relação dos educandos com a cidade do Paranoá, e, a partir das opinióes dos alunos, foram construídos dois textos coletivos. Os alunos falaram como era o Paranoá de ontem com bastante vivacidade, ressaltando vários entraves que tiveram de desafiar. Relataram sobre as dificuldades, a luta diária, a falta de água, o problema com os lotes, como também se lembraram das coisas boas que existiam na época do Paranoá velho, da tranquilidade em que viviam e do respeito ao próximo que vigorava no lugar, inferências que percebemos em alguns trechos do texto coletivo produzido:

Tinha muita poeira. Não tinha comunicação para falar com os parentes de outros estados. Tínhamos que ir pra Rodoviária do Plano Piloto. Às vezes, o caminhão-pipa não vinha e precisávamos ir pegar água no rio São Bartolomeu. Quando nós chegamos no Paranoá, sofremos muito. O Paranoá se formou fruto de muita luta. A vida era dura. Tinha brigas, mas não eram como as de hoje. Era sofrido, mas era bom! Nós criamos nossos filhos com dificuldades e durante o dia íamos trabalhar e à noite, à luz do luar ou com lanternas, buscávamos a água. Quando lavávamos roupa no rio, ninguém mexia com ninguém, porque todos se conheciam e se respeitavam (Trechos do texto coletivo produzido na sala de aula em 26 abr. 2017).

Os(as) educandos(as) contam que, embora as melhorias de uma cidade urbanizada tenham chegado com toda força e náo precisem sair da cidade para resolver mais nada, eles eram mais satisfeitos com o Paranoá de ontem, pois confiavam mais nas pessoas e não tinham medo de sair nas ruas.

Hoje, nós temos tudo. Nós temos água, luz, telefone, posto de saúde, supermercado, internet e hospital, mesmo que precário atende muitas pessoas. Hoje nós vivemos com medo, pois os bandidos tomam conta da cidade. Assim os ladrôes andam soltos e a população presa. A gente 
vive atrás das grades. Antes a gente saía a pé e, hoje, a gente não tem mais coragem (Trechos do texto coletivo produzido no laboratório de informática em 26 abr. 2017).

Ao analisar o texto coletivo produzido pelos(as) estudantes da EJA, um dos participantes do Genpex comentou no Diário de bordo coletivo (2017) que "[...] está muito presente a questão da violência no Paranoá. Estudantes com medo, enjaulados, como disseram. Desses textos já percebemos que a situação-problema-desafio do grupo mais forte é a segurança pública”. A intenção da atividade foi contribuir para que os(as) alunos(as) entendessem que a história do local onde vivem tem importante função social, que promove a interação entre o passado e o presente. A história se faz por intermédio da relação de todos com o meio, porque por ela as pessoas compreendem as transformaçóes que aconteceram à sua volta, atuando como testemunhas de um passado em que outrora foram marginalizadas pelo poder, e que hoje são ressignificaram e valorizaram pela experiência, tornando-se sujeitos dessa história.

\section{Consideraçóes finais}

Este texto começa abordando os desafios da aproximação escola pública e educação popular no âmbito da educação de jovens e adultos. $\mathrm{O}$ artigo evidencia que o uso de tecnologias tem um potencial relevante no contexto da EJA, quando são articuladas à escuta sensível das histórias de vida dos(as) educandos(as), às situaçóes-problemas-desafios e ao texto coletivo.

Os(as) educandos(as) se descobrem como seres capazes, ao utilizarem o computador, possibilitando a descoberta de habilidades que os leva a acreditarem em si mesmos(as). Esse processo é salutar para a elevação da autoestima, do reconhecimento e ressig- 
nificação da identidade, processo que ultrapassa o âmbito da sala de aula, e que instaura no(a) educando(a) convicçóes e esperanças acerca do seu processo de escolarização. A elaboração do livro de histórias de vida e de receitas, seguidos pela "redescoberta dos significados do nome e da história local" são parte do processo de construção de uma prática que acredita "[...] na autoria, na palavra, no processo criativo, na transformação delas mesmas e deles mesmos, na ressignificação da subjetividade-objetividade de cada educando e cada educanda jovem e adulto" (Reis e Sobral, 2017, p. 133).

\section{Referências}

BARBIER, René. A pesquisa-ação. Brasília: Liber Livro, 2002.

BARROS, José Orlando Rodrigues de. A significação identitária da escrita do nome de sujeitos da Educação de Jovens e Adultos em uma escola do Paranoá (monografia). Brasília: Universidade de Brasília, 2016.

BRASIL. SGPR. Marco de referência da Educação Popular para as políticas públicas. Brasília: Secretaria Geral da Presidência da República, 2014.

BRANDÁO, Carlos Rodrigues. A educação popular antes e agora. Formação de educadores de jovens e adultos. Brasília: Secad/MEC: Unesco, 2008.

COELHO, Suzana Lanna Burnier e CRUZ, Regina Mara Ribeiro. "Limites e possibilidades das tecnologias digitais na Educação de Jovens e Adultos”. Anais eletrônicos, n. 31; GT18. Caxambu, Minas Gerais. Rio de Janeiro: ANPEd, 2007.

GADOTTI, Moacir." Educação popular e educação ao longo da vida”. In BRASIL. Ministério da Educação. Secretaria de Educação Continuada, Alfabetização, Diversidade e Inclusão. Coletânea de textos CONFINTEA Brasil+6: tema central e oficinas temáticas. Brasília: MEC, 2016.

GRACILIANO RAMOS. Vidas Secas - 70 anos. Ed. Especial. Rio de Janeiro: Record, 2008.

FREIRE, Paulo. Pedagogia da autonomia: saberes necessários à prática educativa. São Paulo: Paz e Terra, 1996. 
FREIRE, Paulo. Pedagogia do Oprimido. 52 ed. Rio de Janeiro: Paz e Terra, 2014. . Pedagogia da indignação. São Paulo: Ed. Unesp, 2000.

GALVÃO, Ana Maria de Oliveira e DI PIERRO, Maria Clara. Preconceito contra o analfabeto. Sáo Paulo: Cortez, 2007.

JUSTO, Dayane. O uso do computador na EJA como potencializador do processo de alfabetização e letramento no contexto do projeto de inclusão digital do Genpex (monografia). Brasília: Universidade de Brasília, 2016.

LAVE, J., WENGER, Étienne. Situated Learning. Legitimate peripheral participation. Nova Iorque: Cambridge University Press, 1991.

MENEZES, J. S. A construção/constituição do texto coletivo para o processo de dessilenciamento do alfabetizando do Paranoá e Itapoã (monografia). Brasília, UnB, 2013.

THIOLLENT, Michel. Metodologia da pesquisa-ação. São Paulo: Cortez, 1985.

WENGER, Étienne. Communities of Practice: learning, meaning, and identity. Nova Iorque: Cambridge University Press, 1998.

VIEIRA, Maria Clarisse et al. Educação de jovens e adultos como ato de amor, poder e saber: os desafios do Genpex. Brasília, Distrito Federal: Fundação Universidade de Brasília, Decanato de Ensino de Graduação, 2015.

VYGOTSKY, Lev S. Psicologia infantil. v. IV. Madrid: Visor, 2006. 